University for Business and Technology in Kosovo

UBT Knowledge Center

UBT International Conference

2014 UBT International Conference

Nov 7th, 2:45 PM - 3:00 PM

\title{
UBT Inventory of Kosovo's Architectural Heritage
}

Verona Ymeri Hoxha

University for Business and Technology, verona.ymeri@ubt-uni.net

Follow this and additional works at: https://knowledgecenter.ubt-uni.net/conference

Part of the Architecture Commons

\section{Recommended Citation}

Hoxha, Verona Ymeri, "UBT Inventory of Kosovo's Architectural Heritage" (2014). UBT International Conference. 24.

https://knowledgecenter.ubt-uni.net/conference/2014/all-events/24

This Event is brought to you for free and open access by the Publication and Journals at UBT Knowledge Center. It has been accepted for inclusion in UBT International Conference by an authorized administrator of UBT Knowledge Center. For more information, please contact knowledge.center@ubt-uni.net. 


\title{
UBT Inventory of Kosovo's Architectural Heritage
}

\author{
Verona Ymeri Hoxha \\ University for Business and Technology (UBT) \\ Lagjia "Kalabria" p.n \\ 10000 Prishtinë, Kosovë \\ verona.ymeri@ubt-uni.net
}

\begin{abstract}
Architectural Heritage being one of the most prominent fragment of Kosovo's heritage consists of different types of buildings, amongst which apart from those deriving from ottoman era there are individual buildings of high importance which prevail as a form of rebellion to Ottoman intrusion and the desire to intertwine with European architecture. These structures appear in the $19^{\text {th }}$ and $20^{\text {th }}$ century and are characterized with different elements which symbolize a glimpse of escape through reflection of European architecture in Kosovo. This heritage has been a subject of destruction over the centuries, with little or small effort put towards its preservation. Nevertheless, after the war period appears to be more promising with $\mathrm{CHwB}$ persistence to ensure that this legacy is well protected and documented. Documentation of the buildings remains a significant part of heritage preservation, which unfortunately in Kosovo presents a subject of recent awareness. UBT, being one of the Institutions teaching this subject initiated a project which plans to be a never-ending mission of documentation of Kosovo's heritage, through which an eminent contribution towards Kosovo's inventory will be achieved. This project has a double effect, students will gain knowledge and experience as it has been a proven fact that in order to raise professional ethics historical heritage courses should start as early as possible, and on the other hand a direct contribution by UBT to enrichment of Heritage of Kosovo's inventory.
\end{abstract}

Keywords: UBT Inventory, Kosovo's Heritage

\section{Introduction}

It is widely appreciated that the territory of Kosovo holds a wealth of historic cultural heritage. ${ }^{11}$ Architectural Heritage being one of the most prominent fragments of Kosovo's heritage consists of different types of buildings, amongst which apart from those deriving from ottoman era there are individual buildings of high importance which prevail as a form of rebellion to Ottoman intrusion and the desire to intertwine with European architecture. These structures appear in the $19^{\text {th }}$ and $20^{\text {th }}$ century and are characterized with different elements which symbolize a glimpse of escape through reflection of European architecture in Kosovo.

Over the centuries, this legacy has been exposed to destructive actions of both environment and human nature. In the post-war context, Kosovo has inherited a difficult situation in relation to its vandalism that continues today. Unfortunately, institutions dealing with cultural heritage in Kosovo currently possess limited documentation and still face difficulties in entering and recording the heritage being regularly lost. ${ }^{12}$

The documentation of buildings provides a resource of graphical and textual information related to an historic building. It reveals the basic spatial concept of that building and its interconnection with its surrounding context, which will later aid researchers in understanding the social and cultural configuration of a particular society throughout different periods in its history. ${ }^{13}$ Firstly, from the inability to directly influence their physical maintenance, with this assignment we as UBT would like to ensure that this historical fact is recorded, therefore remembered. Indeed, everything started with

11 Cited from 'CHwB Kosovo Office, Report Series No. 15/2010'

12 Cited from 'CHwB Kosovo Office, Report Series No. 15/2010

13 Cited 'Shoshi, S. (CHwB Kosovo Office Director)' 
CHwB's effect in Kosovo in 2001, in times so difficult when cultural heritage could not be regarded even as low priority compared to basic and primary needs of the living and the process of returning to normality. ${ }^{14}$

Secondly, it is therefore necessary that education in cultural and historical heritage begins as early as possible in the course of architectural study because an increased knowledge of and greater commitment to heritage assessment will affect professional ethics towards threatened historic fabric. ${ }^{15}$

Finally, as means of support to this poor state of heritage documentation in Kosovo, UBT has decided to start a project which shall contribute to Kosovo's Heritage Inventory. The aim of this project is to continue for as long as UBT stands and by adding up gradually we will come to a point where almost all architectural heritage in Kosovo is recorded.

\section{Kosovo's Heritage Inventory by UBT and CHwB}

The intention of inventory is to locate the full stock of monuments of a country, to describe it scientifically and therewith serve the protection and care of those monuments as well as the history of art and architecture, the history of the country and the history of the region. This is to the benefit of the vivid (contemporary) art and architecture and strengthens the identity of its population. ${ }^{16}$ This project consists of two parts: the first being third grade students' assignment the aim of which is to give the opportunity to our students to recognize the buildings with potential to be/become country's' heritage, to appreciate it and to learn how to do a professional survey on data collection for our heritage; and the second part being the official documentation of those chosen buildings by creating "an Inventory Website" which will present the official 'publication' of these data's. Similar project was initiated by CHwB in 2010 which was accomplished in cooperation with University of Prishtina students. The output of it was a published pamphlet of treated buildings with focus only in the city of Prizren. The idea of taking a focus in one city at a time was actually a very good one when considering that the result of it was a published book.

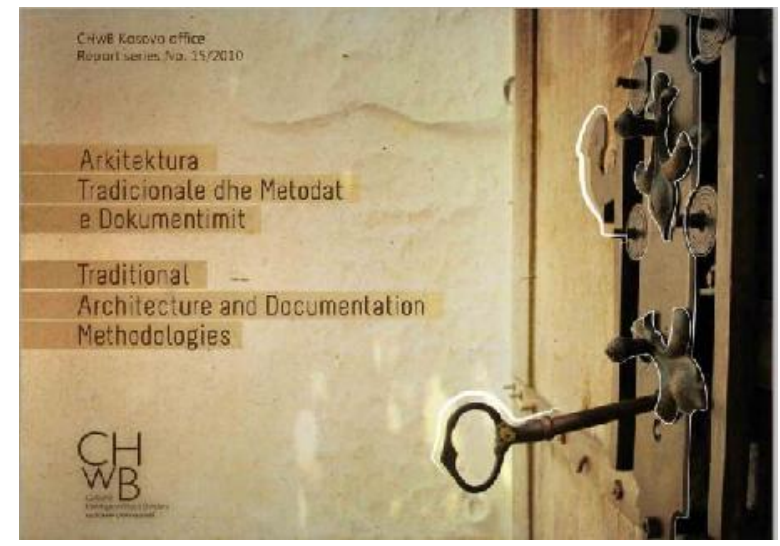

Fig. 6. Traditional Architecture and Documentation Methodologies, Published by CHwB Kosovo Office.

\footnotetext{
${ }^{14}$ Cited from 'CHwB Kosovo Office, Report Series No. 24/2011

15 Cited from 'CHwB Kosovo Office, Report Series No. 15/2010

${ }^{16}$ Cited from Gundsätze für die Inventarisation der Kunstdenkmäler Bayerns, 1904, Heima-tliebe.
} 
On the other hand UBTs project output will be a map of Kosovo in which you could point the cursor and see all the information regarding the desired building.

CHwBs' project can be viewed as a successful project as students that took part did learn a lot on building survey, and although information for buildings are not done in either Dehio's ${ }^{17}$ nor ICOMOS 'format' those buildings are documented nevertheless which in the end of the day reached its main purpose (Fig.2). Unfortunately, its publication was a one-time thing, although there were a lot more similar projects which ended up graded and locked in professors dusty drawers.

UBTs' project preferred intention is to document the buildings which were not yet studied or no physical proof for them being documented exists. In fact, most of the students did actually surprise us with their variety of buildings they chose from different time and style, however, there were a few students that chose buildings that are already documented but which were never put in 'DEHIO's Inventory Handbook'.

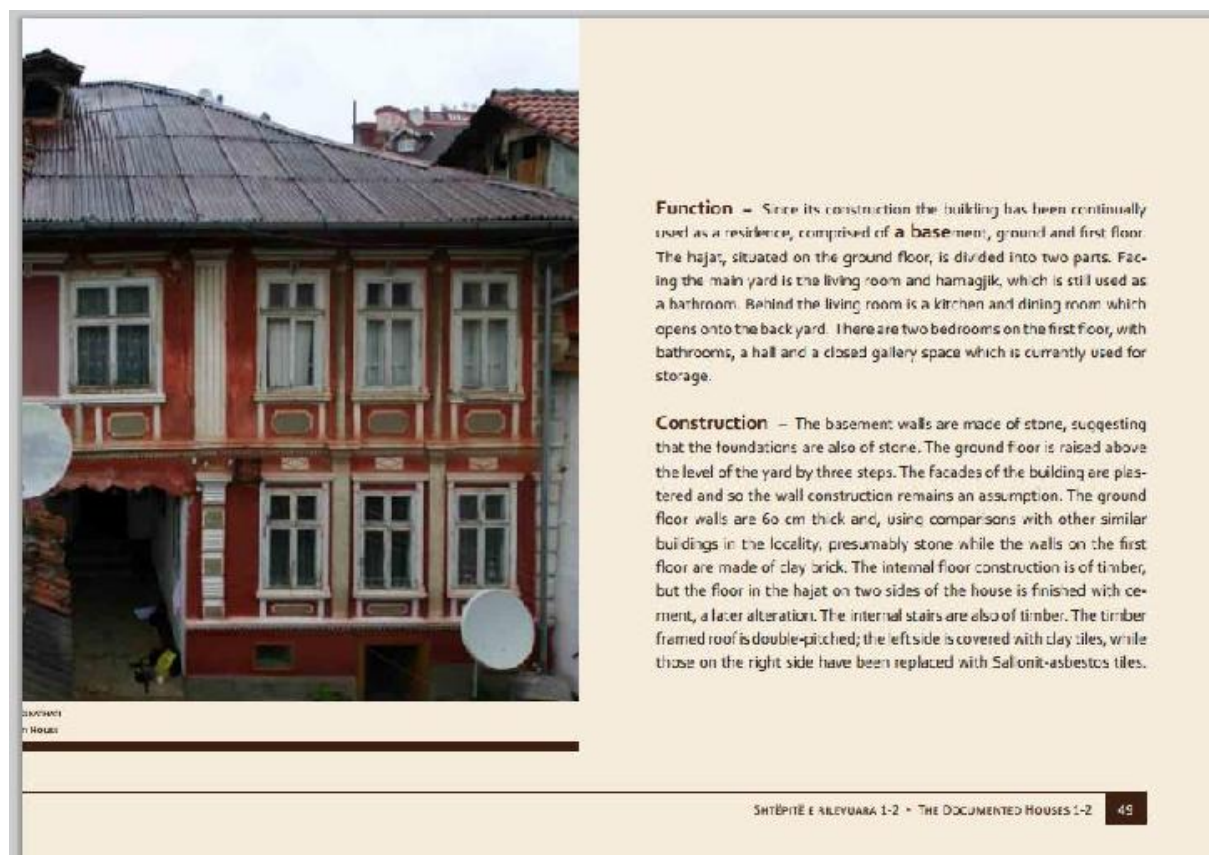

Fig. 2. An example of description given within $\mathrm{CHwB}$ publication for documented building, The House of Rekathati Family, Traditional Architecture and Documentation Methodologie, published by CHwB Kosovo Office.

When compared to CHwBs project (Fig. 3and 4) UBTs project has a disadvantage in the aspect of building drawings as those students who couldn't find the existing drawings for their chosen buildings did the drawings themselves which are more presented as sketches and not in actual scaled dimensions (Fig. 5and 6).

But, in the aspect of categorization of gathered information on buildings present state, UBTs project has a more practical approach since it is using Dehio's and especially International standards of ICOMOS which are used worldwide for heritage preservation. According to ICOMOS guidelines, chapter

17 Dehio Handbuch der deutschen Kunstdenkmäler in der Ostmark. Erster Band. Wien und Niederdonau, Wien-Berlin 1941. 
'Principles for the Recording of Monuments, Groups of Buildings and Sites (1196), recording of heritage is of high importance and with great responsibility which should be taken seriously and done with caution. ${ }^{18}$

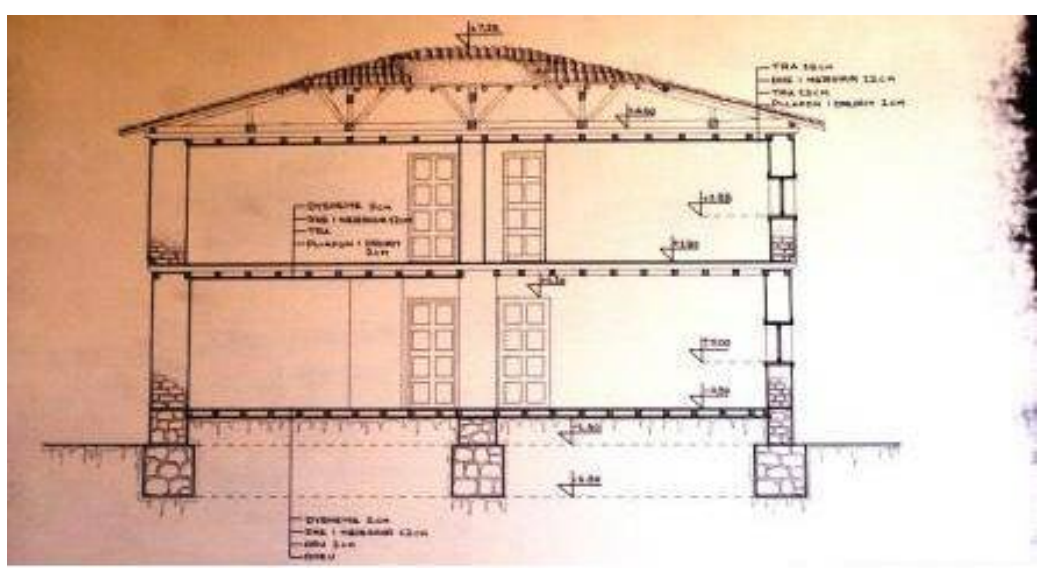

Fig. 3. Production of scaled measured drawings developed by students for CHwB Project, Traditional Architect ure and Documentation Methodologie, published by CHwB Kosovo Office.

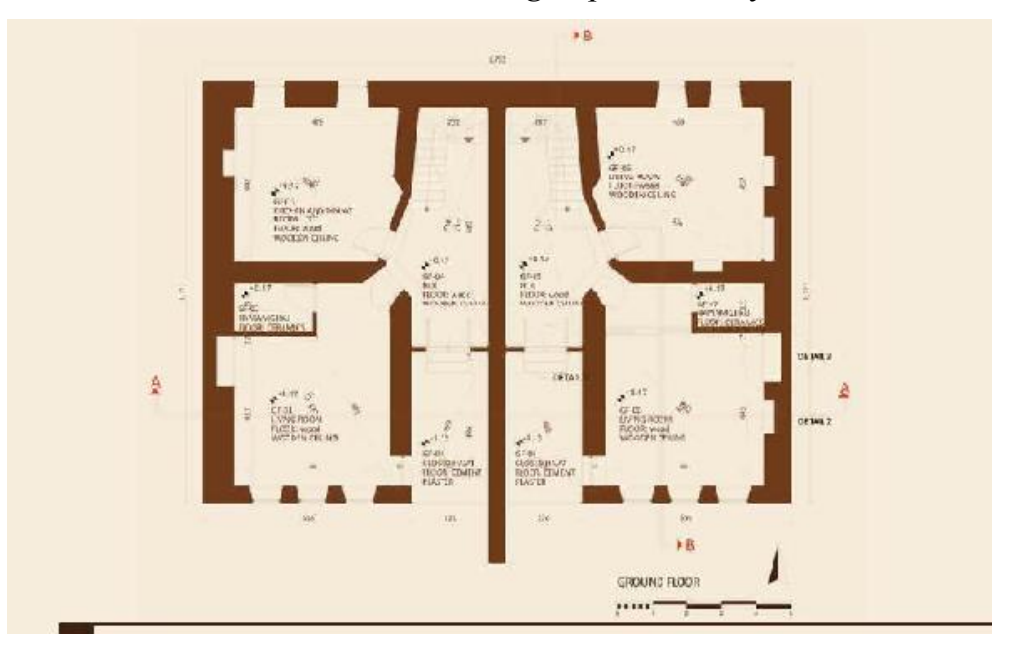

Fig. 4. An example of scaled drawings developed by students for CHwB Project, The House of Rekathati Family, Traditional Architecture and Documentation Methodologie, published by CHwB Kosovo Office.

\footnotetext{
18 'As the cultural heritage is a unique expression of human achievement; and As this cultural heritage is continuously at risk; and As recording is one of the principal ways available to give meaning, understanding, definition and recognition of the values of the cultural heritage; and

As the responsibility for conserving and maintaining the cultural heritage rests not only with the owners but also with conservation specialists and the professionals, managers, politicians and administrators working at all levels of government, and with the public.' 'Principles for the Recording of Monuments, Groups of Buildings and Sites (1196, ICOMOS Guidelines
} 


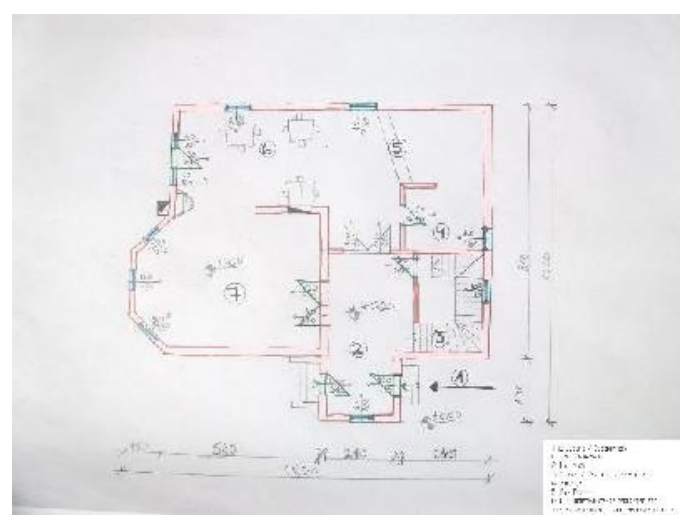

Fig.5.An example of sketched drawings- Ground Floor Plan of Tradita Restaurant, developed by students for UBT Project.

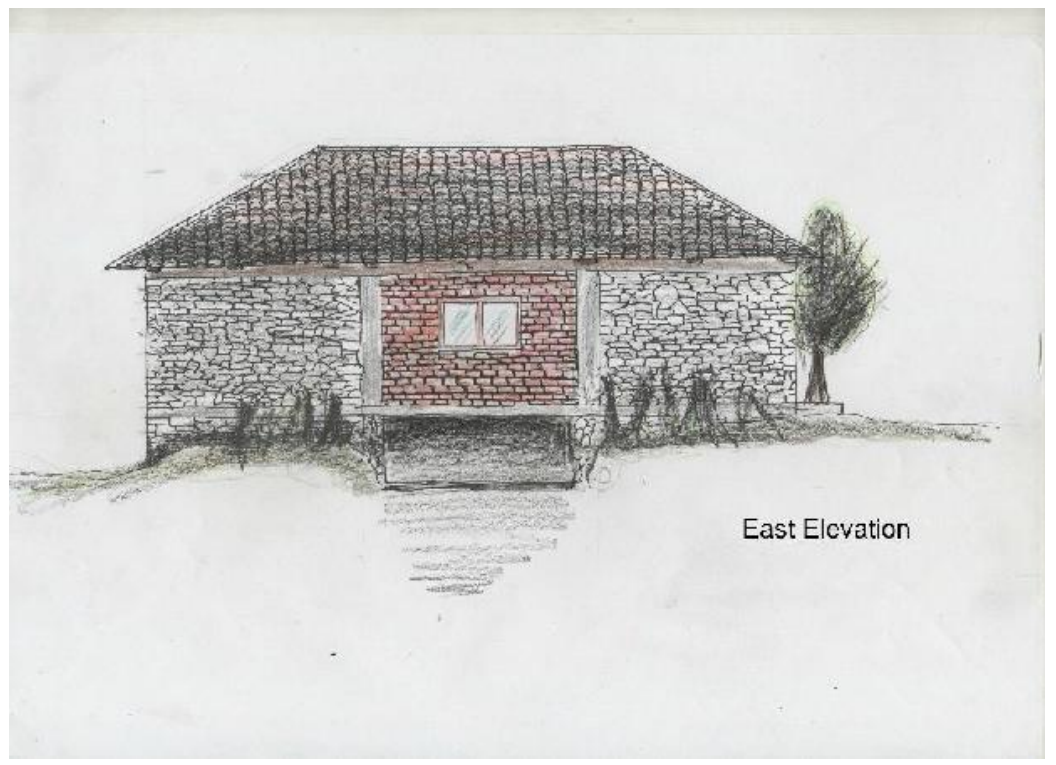

Fig. 6. An example of sketched drawings-Front Facade of Rakaj's Mill, developed by students for UBT Project.

\section{Students Assignment}

First part, students' assignment is in a form of a checklist and each area under the list requires information which was developed by Prof. Dr. Caroline Jaeger-Klein who is the main head behind this project.are in accordance with ICOMOS Guidelines for Building survey as well as George DEHIO's inventory Handbooks. ${ }^{19}$

${ }^{19}$ Dehio Handbuch der deutschen Kunstdenkmäler in der Ostmark. Erster Band. Wien und Niederdonau, WienBerlin 1941. 
One of the points with which students did struggle is the postal address of the buildings, street name, building number, etc. which is currently under development in Kosovo, and by the time the assignment took place not all the buildings had their postal addresses. Hence, students used GPS coordinates which for our age is quite acceptable in terms of practicality, but not as easy to sort in alphabetical order as the community and the street address, which at least the Europeans are used for their postal systems. I believe that this further transforms DEHIO's handbook by adding $21^{\text {st }}$ century advantages of technology.

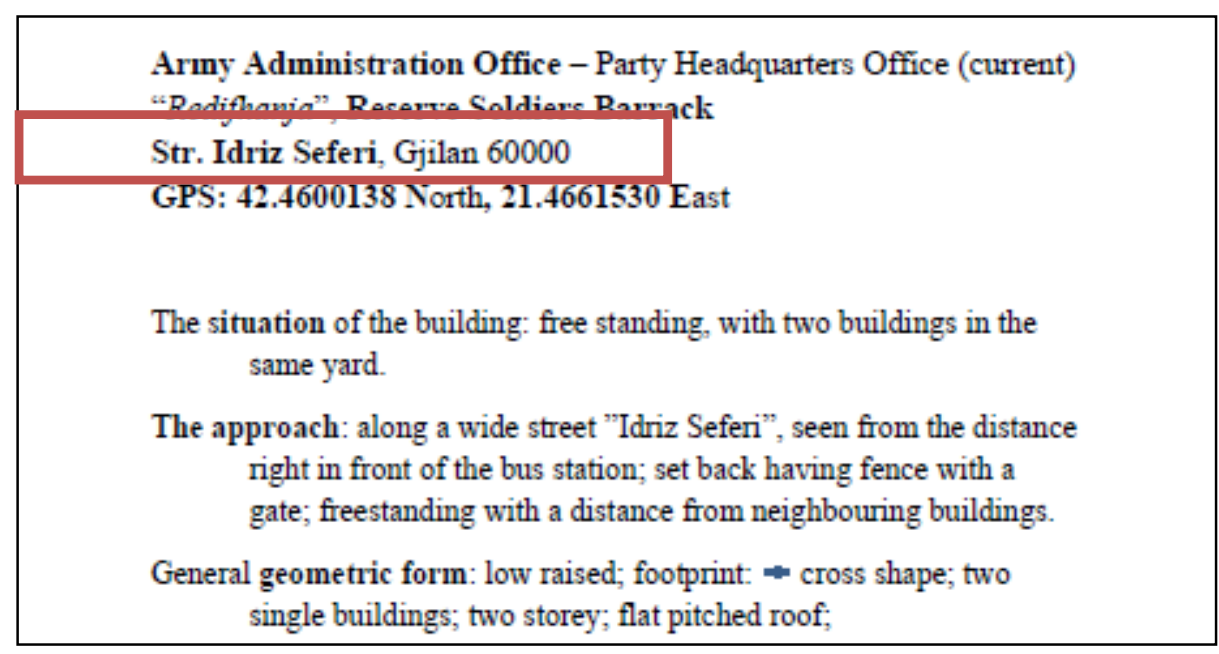

Fig. 7. Other students found it satisfying to provide only GPS coordinates as stands the case of another assignment which did a survey of Army administration Office. This building had an exact postal address which makes it easier to record and identify its location.

Another point in which new technology comes to use is the area where students were required to describe the neighborhood, buildings access, etc. for which some of them found it easier to describe it using Google Earth images. Nevertheless, other students decided to use more conventional methods such as through drawn sketches by hand or computer.

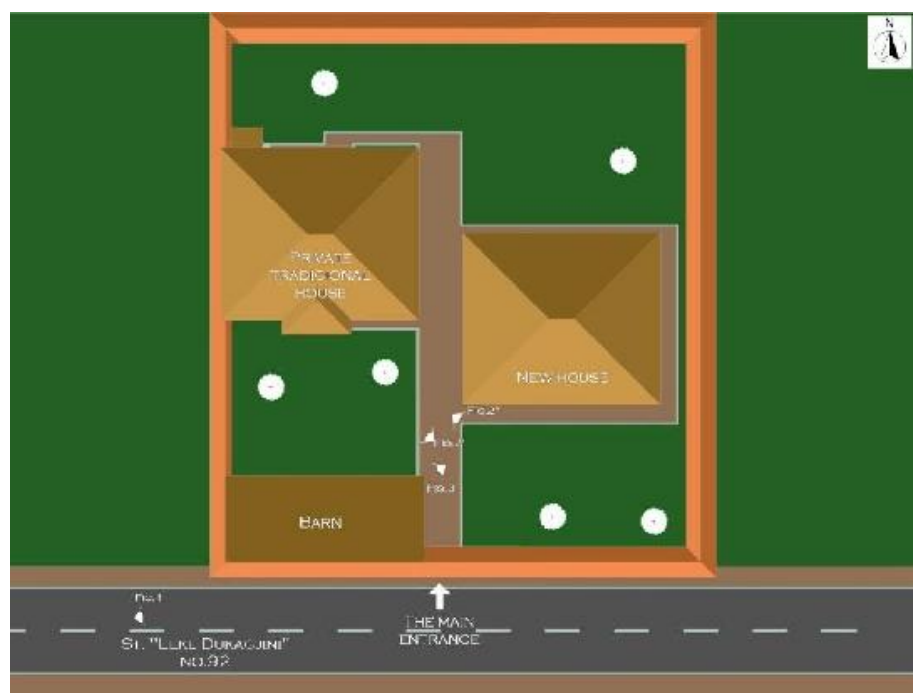

Fig. 8. Site plan of Private Residential Building of Kelmendi Family drawn by UBT student which shows building location against street and cardinal North. This drawing is complimented with GPS coordinates Latitude : $\mathbf{4 2 . 6 5 9 9 3}$ | Longitude : $\mathbf{2 0 . 2 7 8 6 5 2}$ Altitude : $\mathbf{5 2 2}$ meters. 


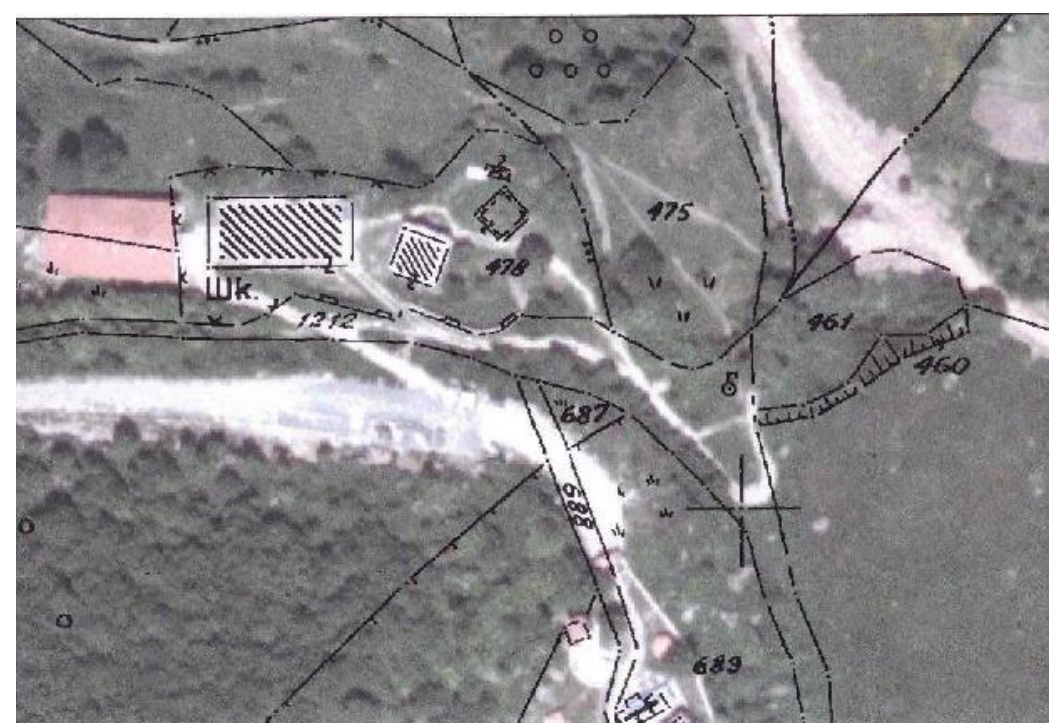

Fig. 9. Site plan of Private Kulla Isa Boletini taken from Google Map

This freedom that students had can be seen positively when it comes to respecting their expression and creativity on doing architectural description on heritage, but, on the other hand when recorded as UBT inventory it did acquaint a problem as it could not be presented uniformly when added in our web site ${ }^{20}$. As a result UBTs inventory consists of combined documents for treated buildings which as the basis uses' DEHIO's Handbook design which together with students way of expression develops into a new form of Inventory that still remains to be developed further.

Even though, these papers were done by bachelor students, some of the papers were at quite high level of professionalism toward documentation of inventory, as per others unfortunately it wasn't the case, which wasn't a result of their lack of competency to accomplish the assignment as much as it was an issue of their possibility to have access to existing inventory on heritage. On the other hand, although these papers do appear as professional, they are repetition of existing documents but rather presented in DEHIO's format as they are documenting already treated buildings which contribute to UBT's inventory but unfortunately do not do the same for Kosovo's Inventory. When we are at this point in the future assignments we should be more careful in predefining building types, which will make it possible for UBT to make groups of buildings which will be characteristics for each academic year and prevent inventory repetition.

Examples of these very good papers include buildings treated below:

${ }^{20}$ Students papers were used to create a data base in our web site in which one can find UBT's Inventory on Kosovo's Heritage. 


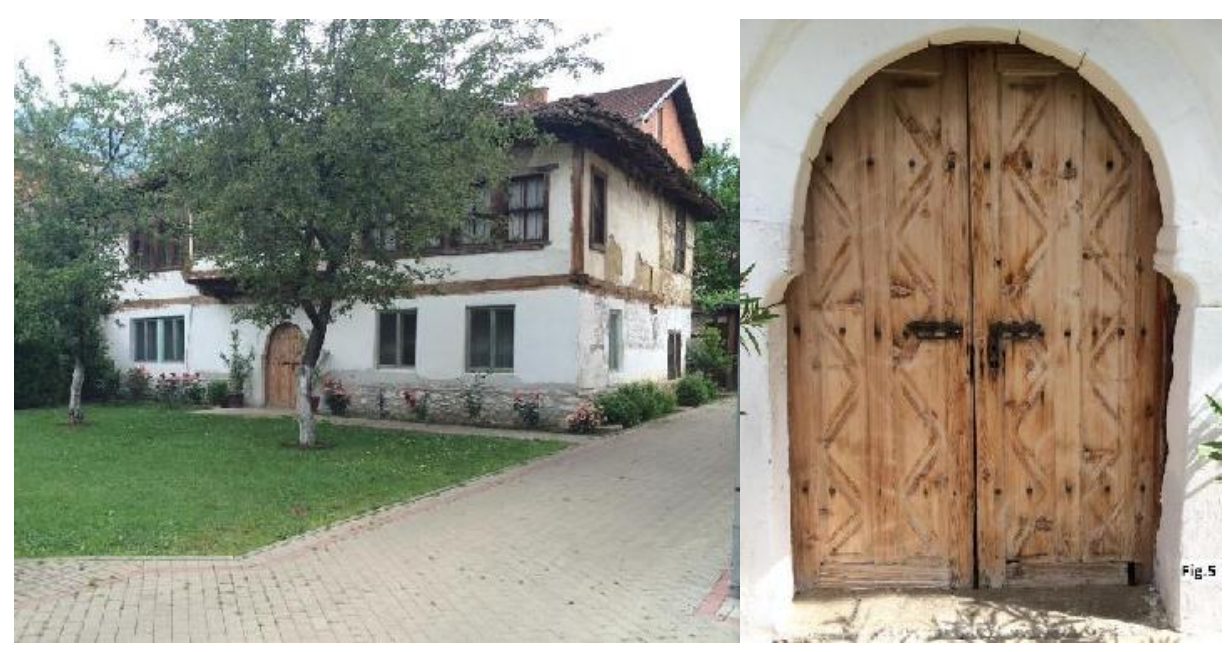

Fig. 10. Photographed by UBT student, Private Residential Building of Kelmendi Family

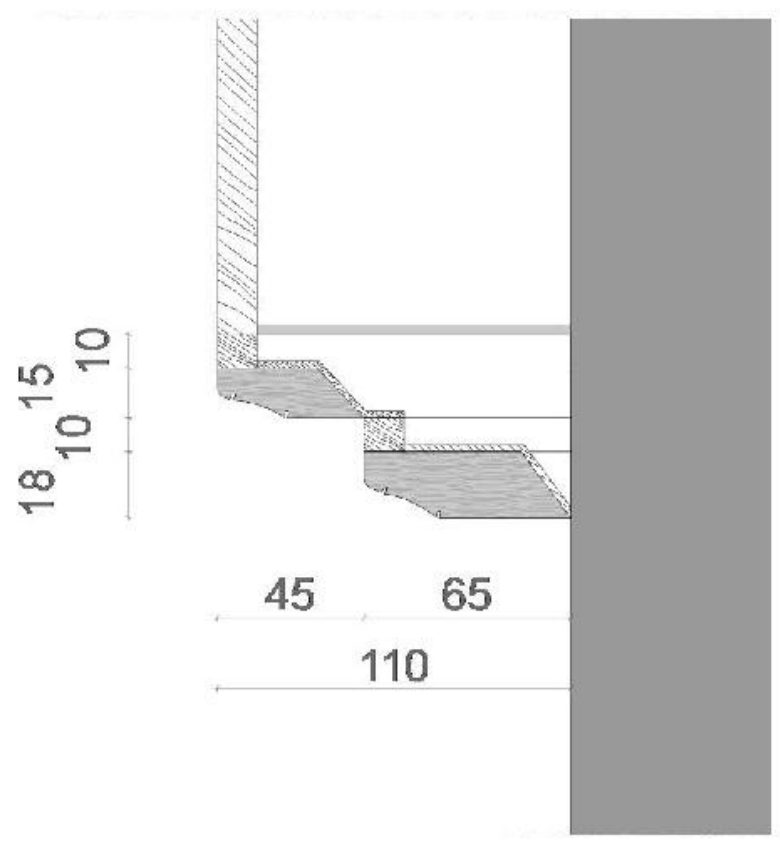

Fig. 11. Drawing by UBT student, constructive detail of 'Cardak', Private Residential Building of Kelmendi Family 


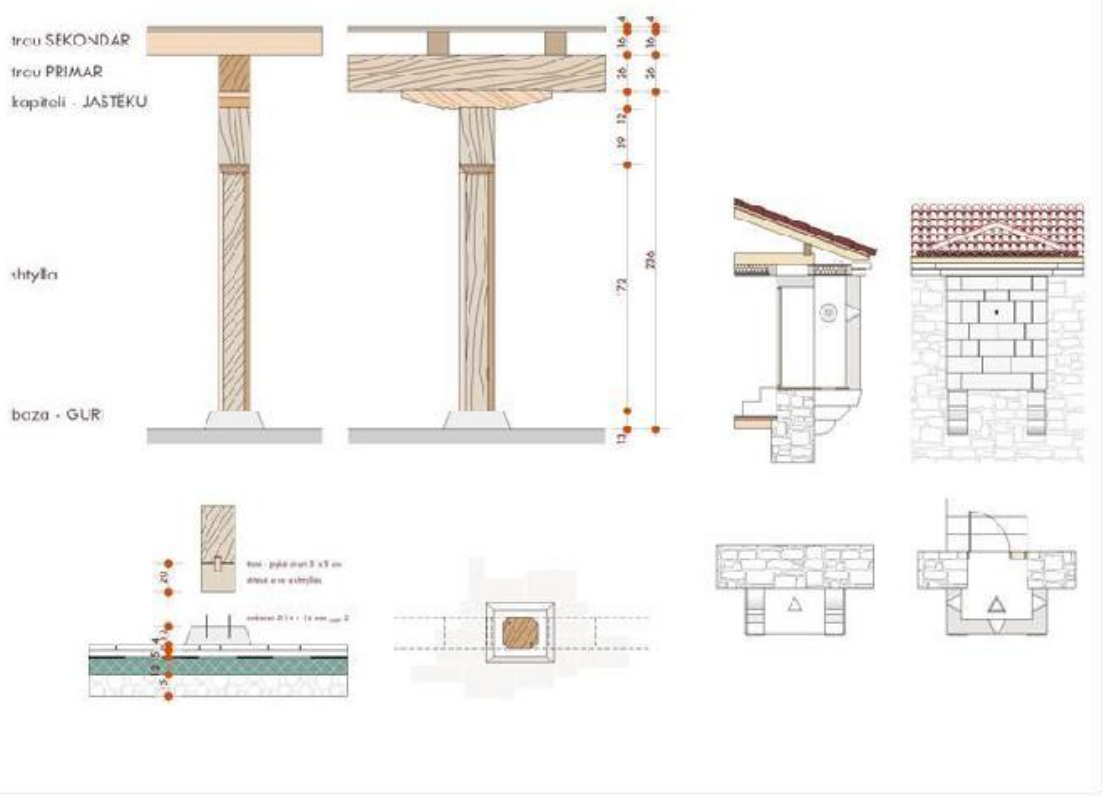

Fig. 12. Drawing by UBT student, constructive detail of internal toilet, Kulla Isa Boletini

\section{Conclusion}

As a result of this project for initial phase we have 15 recorded buildings ten of which were never documented before. Although the drawings and information for buildings are not as complete as would be done if provided by professional surveyors, it still represents a momentum in history of documentation of Kosovo's Heritage according to Dehio's Handbook and international guidelines of ICOMOS which serve as Europe's references.

This initiative is a positive and adequate step for our Heritage in general and I believe that if continued will become a standard form to be used when doing a building survey. With further development and hard work by both students and professors it could reach the desired level which might be used as an official draft of heritage documentation and through which an enormous amount of data will be recorded to be used for conservation and/or preservation. As a result of this both our students and Kosovo benefit equally; students by learning to appreciate our heritage and Kosovo by having a set up system of heritage documentation.

\section{References}

1 CHwB KOSOVO OFFICE (Report no. 15/2010), Traditional Architecture and Documentation Metodologies, Prishtinë (2010) 49-58

2 CHwB KOSOVO OFFICE (Report no. 24/2011), Traditional Architecture and Documentation Metodologies, Prishtinë (2010) 30-35

3 PRINCIPLES FOR THE RECORDING OF MONUMENTS, GROUPS OF BUILDINGS AND SITES (1996)-ICOMOS INTERNATIONAL GUIDELINES PG. 49

4 Gundsätze für die Inventarisation der Kunstdenkmäler Bayerns, 1904, Heimatliebe 
5 Dehio Handbuch der deutschen Kunstdenkmäler in der Ostmark. Erster Band. Wien und Niederdonau, Wien-Berlin 1941.

6 UBT Student Assignment (Agon Gacaferi), Private Residential Building of Kelmendi Family, 2014.

7 UBT Student Assignment (Ard Gashi), Kosovo Institute for Monuments Protection , 2014.

8 UBT Student Assignment (Ermal Krasniqi), Kulla Isa Boletini, 2014.

9 UBT Student Assignment (Arian Sefiu, Shkumbim Krasniqi, Arber Kryesiu), Army Administration Office, 2014.

10 UBT Student Assignment (Ernes Hajdari), The first Albanian School, 2014.

11 UBT Student Assignment (Florim Gashi), Tradita Restaurant , 2014. 